DOI: 10.20472/IAC.2019.048.024

\title{
SUMITTRA JIRAWUTTINAN
}

Mahasarakham Business School, Thailand

\section{THE IMPACT OF SOCIAL CAPITAL CAPABILITIES ON PERFORMANCE OF SMALL AND MEDIUM ENTERPRISES IN THAILAND}

\begin{abstract}
:
The main aim of this study is to test the effect between social capital capabilities and SME performance via entrepreneurial capability as mediating variable on the relationship. The model is verified by collecting data from 340 small and medium enterprises in Thailand and mail survey questionnaire is used as instrument. The statistical analysis for testing the hypothesis is OLS multiple regression analysis. The results showed that four dimensions of social capital capabilities (network capability, trust, communication and collaboration) have positive effect on entrepreneurial capability and SME performance. All dimensions of social capital capabilities can explain predication of entrepreneurial capability at $40.70 \%$ and SME performance at $38.90 \%$. In addition, two independent variables such as trust and collaboration are fully support hypotheses. Overall, this study contributes to SME manager by exploring that social capital capabilities and entrepreneurial capability can be achieved SME performance
\end{abstract}

\section{Keywords:}

Social Capital Capabilities; Entrepreneurial Capability; SME performance, Small and Medium Enterprises 